Present Status of Fusion Researches in USA, (II)

\title{
V. ローレンスバークレイ研究所における現状
}

Controlled Fusion Research at University of California

Lawrence Berkeley Laboratory

By R.V. PYLE*

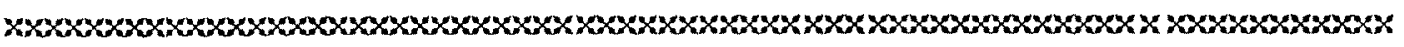

カリフォルニア大学ローレンスパークレイ究究所で

は，磁気核融合および慣性核融合の研究を行なってお

り，とくに新しい技術の開発研究を行なっている。

磁気核融合に拈いては，プラズマ加熱，然料注入，静 電ポテンシャルの調整,プラズマ揨断,そして将来の核 融合纱プラズ、規模のプラズマにおける current drive 実験等に必要な中性粒子入射システムの開発が主要な テーマである。

慣性核融合においては，大電流，大エネルギーの重 イオンを然料ベレットに照射して加熱するに必要な加 速器の開発を行なっている。

\section{I.はじめに}

カリフォルニア大学ローレンスハークレイ研觉所

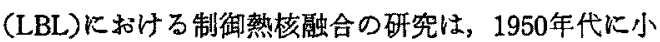
规模なピンチ奻果和よびミラー磁場によるブラズマ閉 じ込めの研究に始まった。このらちミラー磁場の研究 プロシェクトは間もなく新設されたローレンスリバモ ア国立研究所に移された。D-D反応によると思われる 多量の中性子が検出されたため，ピンチによる閉じ込 めの研究は1950年代中頃に発展し始めた。しかし，す ぐここの性子は熱核嘱合により発生したものではな く，わずかの数の重水素が急速に成長したりーセージ 不安定性により高エネルギー(およそ $100 \mathrm{keV}) に$ 加速 されたために，作り出されていることが明らかになっ た。これら多くの興味ある研究課題のため, 大学院生 の協力を得て，ピンチや回転ブラズマにおけるエネル ギー蓄積、アルベン波の発生および后播，高周波による プラズマの生成およびこれらに関係した核物理等にお。 いて，多くの実験研究が行われた。また，プラズマの 統計的性質についての理論的考察も始まった。 1971年にプラズマグループに特いて，プラズマ物理
の基礎研究に加えて，さらに核融合に応用するための 技術研究す始まった。とりわけローレンスリハモモフ国 立研究所の R.F. Post 执よび T.K. Fowler は，中性粒 子の荷電粒子に換算した等価電流值を，数 $\mathrm{mA} か ら$ 数 $10 \mathrm{~A}$ に增大させることが可能であるならば，ブラズマ の加熱就よび然料の注入に非常に役立つことを指摘し た。そこで LBL では $20 \mathrm{kV}, 10 \mathrm{~A}, 20 \mathrm{~ms}$ バルス長の 性能を满たすイオンソースモシュールの開発を開始し た。やがて中性粒子入射システムの開発は核融合に拉 いて大きな地位を占めることになり，現在に至ってい る。

磁気核融合の研究活動は, LBLに括いて Accelerator and Fusion Research Division において行われている。 1977年からはも51つの核融合に関する研究，すなわ ら慣性閉じ込めの研究もこの Divisionに扎いて始まっ た。これはレーザーを使ら代わりに，高ェネルギー (GeV)の重イオンビームをぺレットにあててプラズマ をつくり，それが熱核融合反応を始めるまで急速に加 熱するるのである。LBLに扎いては特にパルス大電流 加速器とその輸送システムの開発研究が行われてい る。

現在の LBL の主な役割は，ブラズマ加熱,ブラズマ への然料注入, そしてプラズマ診断のための新しい技 術の開発であり，さらに、プラズマの諸問題について 実験的かつ理論的基喽研究を行うことにある。また学 生を一般企業を含め米国に打ける他の核融合プログラ ムに必要な技術者や物理学者に差成することるこの研 究の重要な役割の 1 つである。

以下,最近の主な研究活動のいくつかを紹介すると

*米国カリフォルニフ大学ローレンスパークレイ研究 所(Univ. of California Lawrence Berkeley Lab., USA)（1983年 7 月 2 日 受理） 
ともに，令後数年間のわれわれの研究活動について述 ベる。

\section{II 中性粒子入射システムの開発研究}

ここ10年間の主な活動は, 2 XIB, TMX (Tandem Mirror Experiment), DII(Doublet II), TFTR(Tokamak Fusion Test Reactor), そして MFTF-B(Mirror Fusion Test Facility-B)のプラズマ加熱に必要な中性椟子入射 システムおよびそのュンポーネントの開発にあった。 これらなべての中性粒子ビームは, 正イオンの生成, 加速怙よび中性化による力式に基ついて開発されたる ので，この中で最も高エネルギーのむのは，プリンス トン大学プラズマ研究所の TFTR 実験のためのもの で, $120 \mathrm{keV}, 65 \mathrm{~A}, 0.5 \mathrm{~s}$ 満たす12基のモシュール により，4つのビームラインを通して，TFTR中のプ ラズマに $18 \mathrm{MW}$ の中性重水素ビームを打ち込むこと ができる。

General Atomic (現GA Technologies)の DII 実䮖の

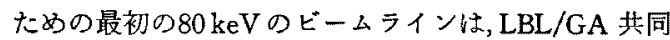
で設計開発された。この実験のための最後の $80 \mathrm{keV}$ ， $0.5 \mathrm{~s}$ のースモジュールは, LBLでちょうどテストを 終了したところである。

MFTF-Bの実験に乱いては，ほぼ同型の80 keV, 0.5 s, そしてさらにいくつかの $80 \mathrm{keV}, 30 \mathrm{~s}$ のソースモジ ュールが必要であるが,イオンソースの運転時間を0.5 から30sまで延ばすには大きな技術的進歩が必要であ る。それは,プラズマ領域や加速領域の構造材(電極等) の熱容量では, 1回のパルス運転の間に出る熱量をすべ て蓄えることができないためですべての部分を充分

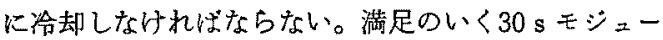
ルが完成したことを示すためには，それにふさ秃しい テストスタンドが必要である。そのためめ大きな国内 共同利用テストスタンドが LBL に完成した。これは Neutral Beam Engineering Test Facility (NBETF)と 呼ばれる施設で， $80 \mathrm{keV}, 40 \mathrm{~A}, 30 \mathrm{~s}$ の重水素モシュ ールを10\%の duty factor でテストすることができ， また重水素の使用に耐えるよう充分な中性子遮蔽が施 されている。

正イオンンースの開発段階で，特にアーク放電乩よ び中性化セルの中でいくつかの與味あるプラズマ物理 に関する問題が研乫された。正イオンは“magnetic bucket”の中の大電流放電によってつくられたブラズ $\checkmark\left(n \approx 10^{12} \mathrm{~cm}^{-3}\right)$ から引き出されて加速される。ここ で"magnetic bucket”とい5のは壁面が永久硪石の多極 磁場配列で覆われた容器のことで，これルよってプラ
ズマ中の電子执よびイオンの閉じ这め時間を長くする

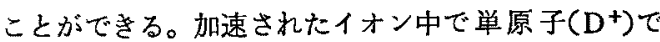
ある割合をいかに大きくできるかといらことは，非常 に大切な問題の1つである。というのは分子イオン

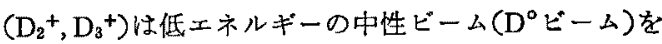
派生するので好ましくい。われわれの実験結果括よ びそれに伴ら理論的考察により，イオンの引き出し領 域の電子温度が低く，からイオン生成領域の電子温度 が高い場合, $\mathrm{D}^{+} /\left(\mathrm{D}^{+}+\mathrm{D}_{2}{ }^{+}+\mathrm{D}_{3}{ }^{+}\right)$比率が極めて高く なることが明らかとなった。実験装置を第1図に示寸。

フィラメントから放出された電子は，放電容器の長 さよりも長い平均自由行程を持っている。電子は，容 器の外側に取り付けてある列状の永久磁石の磁場によ って壁面で反射され，電離あるいは解離によって， $\mathrm{D}^{+}$ および $\mathrm{D}_{2}{ }^{+}$オンを容器内に一様につくり出す。すた $\mathrm{D}_{2}+$ イオンと $\mathrm{D}_{2}$ 分子間の反応によって $\mathrm{D}_{3}{ }^{+}$イオンすつ くられる。数本の長くて薄い棒状磁石によってっくら れる横向きの弱い磁場によって，放電容器を 2 つ領 城に分けることができる。これによっで"source”領域 の亮エネルギー電子が, “extraction”領域に流れ込む ことを，衝突の助けを借りずに妨げることができ， “extraction”領域の電子エネルギーを低くすることが できる。“extraction”頒域の低ェネルギー電子は $\mathrm{D}_{2}+1$ オンをつくることはできないが， $\mathrm{D}_{2}+$ を解離すること により $\mathrm{D}^{+}$の割合を増やす。プラズマを2つの異なっ た電子温度を持った領域に分けるこの方法は，負イオ ンの生成など他にも応用することが可能である。

\section{III. 負イオン源の開発研究}

負イオンを加速して中性化する原理に基づいた中性 粒子入射システムは，ますなくBLに拉ける主要研究 および開発テーマとなるであるう。負イオンが有益な ことは、第 1 表拈よび第 2 图を見れば明らかであるら。

第 1 表は，現在米国において検討されている核融合 炉に必要な中性粒子入射システムの主要諸元である。 实際につくられる核融合师は，第 1 表に示されたるの

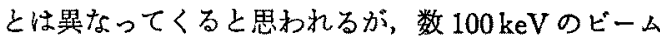
エネルギーが必要とされることは明らかである。

第 2 図は，正イオンの中性化される奻率が高エネル ギー領域では極めて低いことを示している。一方，負 イオンの方は原理的には $100 \%$ に近い中性化効率を得 ることがでさる。

大型の負水素イオン源には現在 3 つの方法が考えら れており，開発研究の行われた順に以下に説明する。

まず，荷電交換を利用した正イオンの負イオンのの 


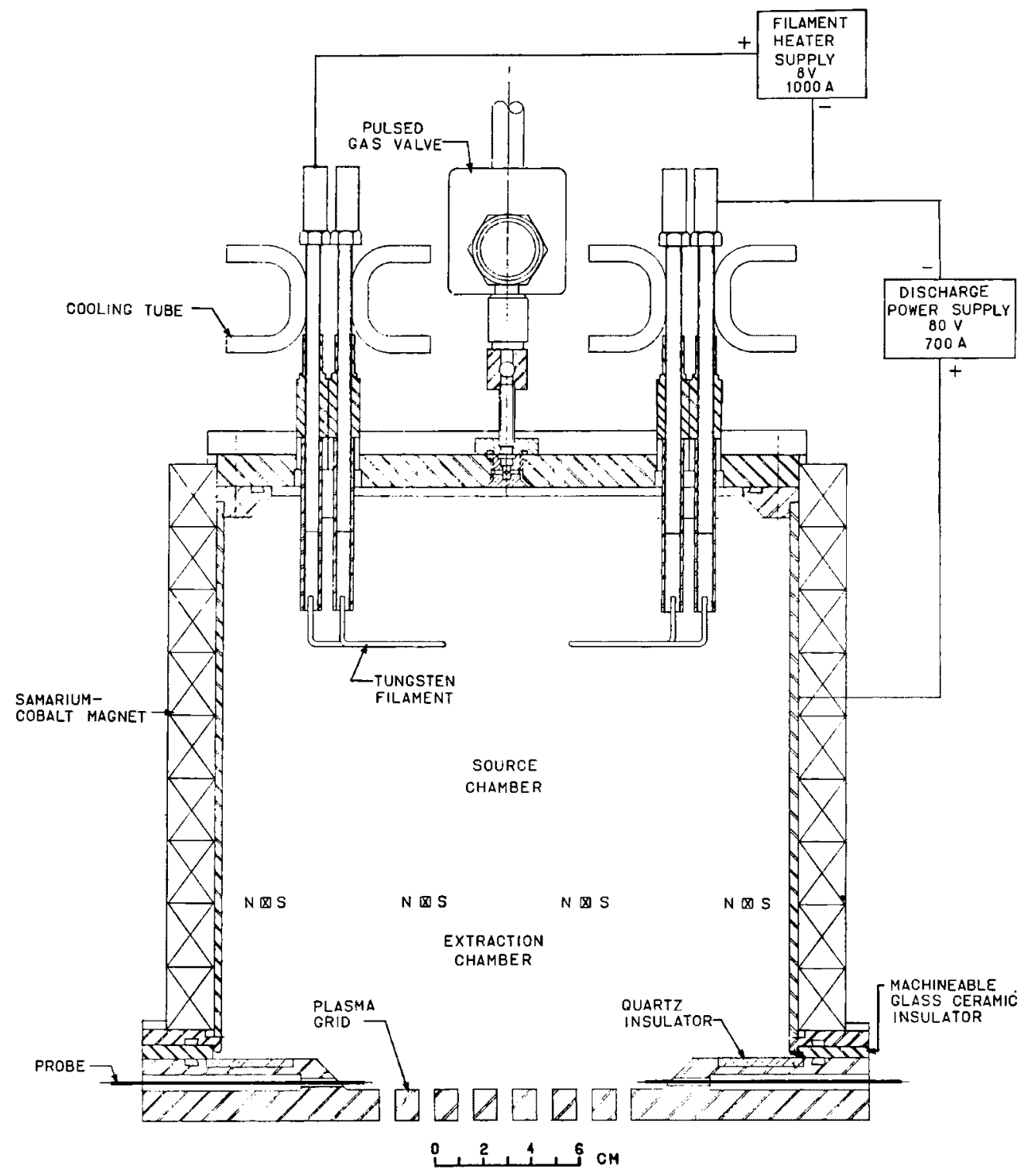

第 1 图原子イオンの此率を高めるための“磁場フィルタ”プラズマ源

变換実臨が行われた。これは大電流，低エネルギー正 イオンビームが, アルカリあるいはアルカリ土類金属 の蒸気の中を通ると, $\mathrm{H}^{+}, \mathrm{H}^{\circ}$ おび $\mathrm{H}^{-}$の混合物とな って出てくる性質を利用したるのである。実際 thick targetから得られる負イオンは低イオンエネルギーに おいては $50 \%$ にる達する。しかしながら，実用的な観 点からは，利用できる正イオンの密度および散乱や空 間電荷の効果等の影響も考㦄しなければならない。

この方式では，複雑な装置である重金属を使った荷
電交換七ルが必要で，またその重金属蒸気が核融合装 監を污染する可能性が大きいため，この方式による負 イオン源開発は surface productionによる方式に比へ て実用的でないと考えられ，現在米国においては，こ の方式に基ついた開発は行われていない。

現時点で採用された方法は，プラズマイオンおよび 中性粒子を金属表面へ衝突させることによって負イオ ンをつくる方法(surface production)である。負イオン の生成奻率は大きな原子番号ならびに低い仕事関数を 
第 1 表 核融合炋化必要な中性粒子入射滧㯰の代表的性能

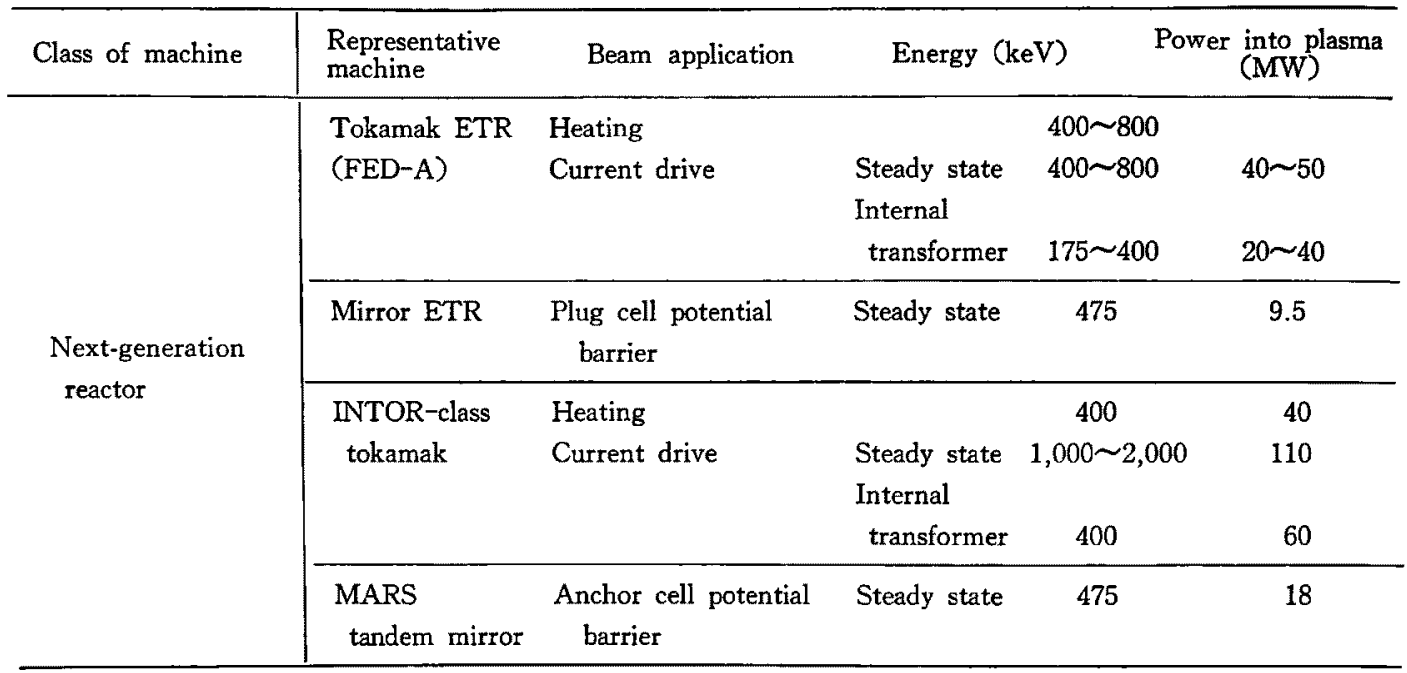

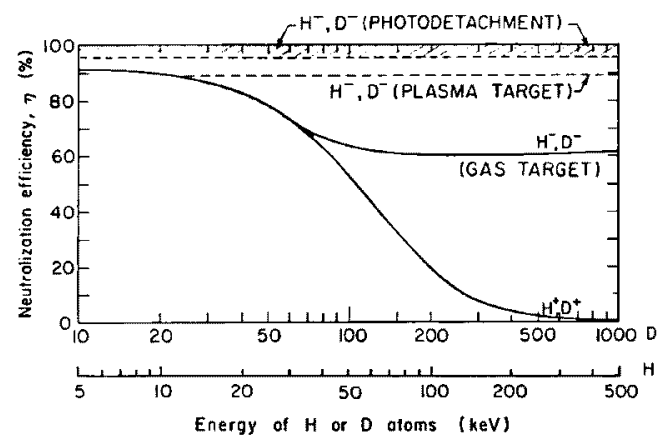

第 2 图正拉よび負イオンの最大中性化效率

持つ金属表面で一番高い。低い仕事関数を得るために は放電中にCs を加える。これにより Csの一部は金 属表面について部分的に単原子算をつくる。1 A の負 イオン源の概要图を第 3 图に示す。

プラズマ中の volume productionによる $\mathrm{D}^{-1 オ ン の ~}$ 生成は現在の砛究テーマの 1 つで，Csを必要としない ので将来最も有望な負イオンをつくる方法として注目 されている。といらのは加速器中閉じ込め装䈯の近く でどちらかといえばCsを使用したくないからである。

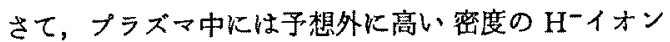
が存在していることが知られている(核融合㸚置に必 要な大電流を volume productionにより得られるかど 5か，また充分に電子およびガスを制梅できるかど かが，今後の研究課題である)。

いま提案されている負イオンの生成原理は，振動励 起状態の水素分子に，低エネルギーの電子が dissociative attachmentするためであると考えられている。

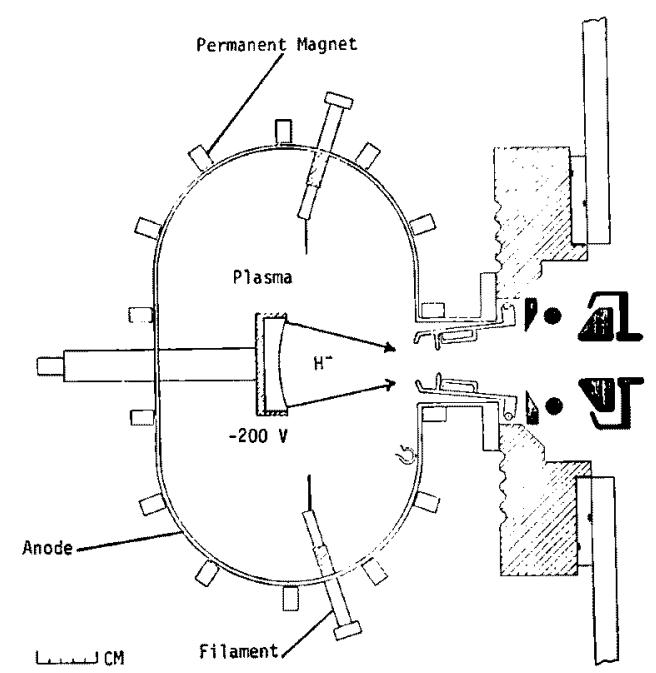

プラズマからの正イオンはプラズマ中に設けられた 低仕事関数の弯曲した金属表面に衙突する。生じた 負イオンはー200V のバイフス電界により，表面よ り加速され，右側の加速部へと収束される。

第 3 図 1 A surface production 負イオン源

すなわち

$$
e+\mathrm{H}_{2}(v>6) \longrightarrow \mathrm{H}_{2}{ }^{-} \longrightarrow \mathrm{H}^{-}+\mathrm{H}
$$

プラズマや容器の壁面における振動励起状熊の分子の 生成および消減が今後の重要な研究課題である。

\section{IV. 他 $の$ 研 究}

原子核が偏極した核融合然料を使らことが現在興味 をもって探究されている新しい課題である。すし偏極 
状態を充分に長く作り出せるならば，2つの効果をむ たらすことができるすななち，まず反応散乱断面積 をふやすことす減らすこともできるし，さらに反応生 成物( $\alpha$ 粒子, 中性子など)の飛ら゙方向を調整すること が可能となる。然料を核融合ブラズマに供給する3つ の方法(neutral beams, gas puffing, pellet injection) の5ちで，現在高エネルギー中性粒子が大きな運動エ ネルギーを持っているため，最む望むしくない方法と 考光られている。しかしながら，結果が何であれ、こ れは応用物理としては非常におるしろい分野である。

いかにして多量の偏须した重水素就よび三重水素を 作ることがでるだろらか。プラズマイオンが真空容 器の壁まで抎散した時あるいはブラズマに戻る時の depolarization 確率はどのくらいであろらか。LBLで 行われている関連研究への展望は，ひとえにこれらの 問題への解答いかんにかかわっている。

粒子と波の相互作用の研究は，基憷プラズマ理論グ ループKよって general geometryk批いて行われてき た。ここでは6 次元相空間(position, wave vector)にお ける action density および 5 次元相空間(position, parallel velocity, magnetic moment) К呫ける guiding center density の概念を用いている。

非共鳴効果は energy function から導かれ、また incoherenceへの透移やcoherent wave, incoherent wave の両方を取り扱うことができる。波は互いに非線形に 干䟞し合らとともに：ヘックグラウンドのプラズマと る相互作用する。後者の相互作用は, discrete effect お よびcollective effect, 線形および非線形効果,さらに共 鳴および非共鳴効果を含む。これらの式は self consist-

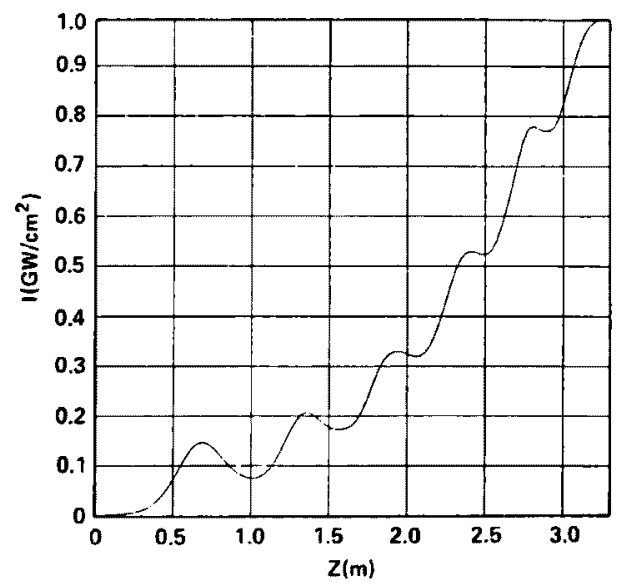

第 4 图 $4 \mathrm{MeV}, 500 \mathrm{~A} / \mathrm{cm}^{2}, 100 \mathrm{GHz}$ 自由電子 レーザーの理諭的 radiation intensity vs. amplifier length ency が満たされるように組み立てられており,プラ ズマ不安定性,乱れ，そしてプラズ、の波動加熱に応 用することができる。

閉じ込められたブラズマを加熱するもら1つの方法 に，高出力のマイクロ波のエネルギーをプラズマに吸 収させる方法がある。研究上興味のある周波数領域は $100 \sim 200 \mathrm{GHz}$ である。強い相対論的電子ビームが, 電磁石によって周期的に偏向さ礼て光を発生する自由 電子レーザーを使うと，原理的には高い効率で大きな 出力を作り出すことができる。ローレンスリバモア国 立研究所との共同研究に上り, 空間電荷場拉上び輻射 場において self consistent に解析してデザインされた

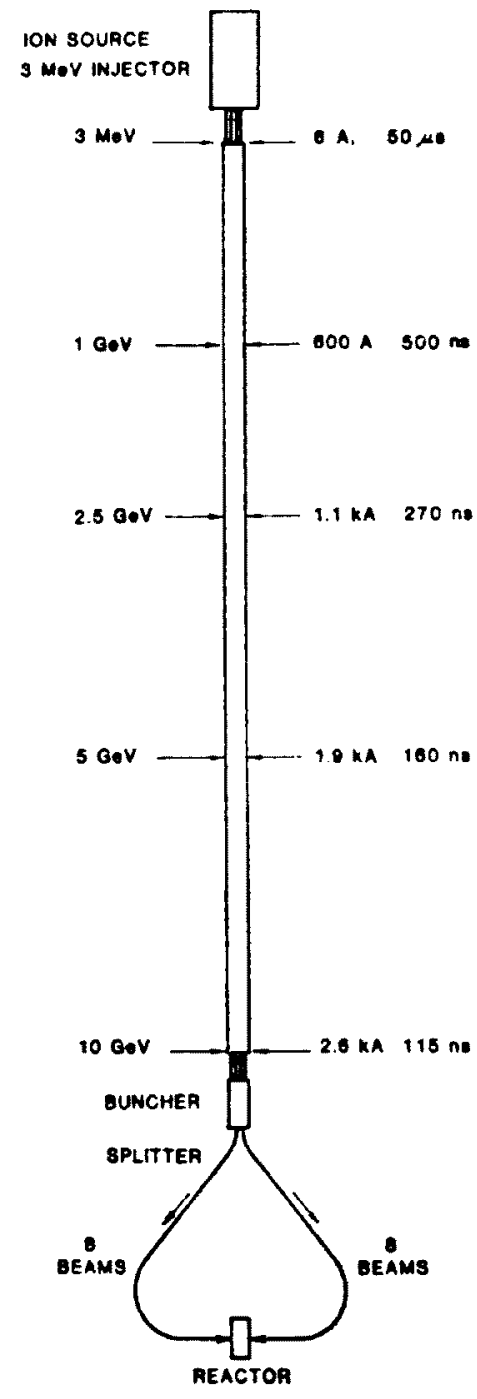

第 5 图 誘導加速器を用いた重イオン 核叞合システムの概略図 
システムが目下テストされている。これは GW 級の $100 \mathrm{GHz}$ マイクロ波パルスを作り出せるるので，実験 では $1 \mathrm{kA}, 4.5 \mathrm{MeV}$ の電子ビームを使用している。 wiggler 中での代表的な radiation power density vs. position の結果を第 4 図に示す。

LBL に打ける慣性核融合(ICF)の研究は,大電流, 重 イオン加速器を使って電気エネルギーを作り出すこと を指向している。重イオン慣性核融合システムの概要 図は第5図に示されている。LBLに护開発計画で は，100Aソーセーシ型ビームを短パルス，数kA，数 $\mathrm{GeV} ヒ ゙ ー ム K$ 加速変换するために, single-pass linear accelerator中に多くのinduction-modulesを使っている。

複数の平行テャネル中で加速されたビームは燃料ぺ レットKぶつかり，京よそ $10^{25} \mathrm{~cm}^{-3}$ の密度のプラズマ を作る。これは磁場によって閉し込められた核骶合师 よりひ扣よそ $10^{10}$ 倍密度が高い。この加速器の初段部 はLBL でテストされている。また beam opticsの研究 㸝よび診断方法開発のためCs ビームが用いられてい る。

\section{V. 将来の計画}

将来の展望として，まず中性粒子ビームのプロジェ クトから述ベる。正イオンを使用した中性粒子システ 么は1990年代も使用されると思われるが，LBLにおい て研究開発のための活動はあと 2 年程度で終了するで
あろら。 $\mathrm{D}^{+}$比率を90\%にふやし，不純物をできるだ け減らすことがこの分野の最主要研究テーマであり， また重要な課題は中性粒子システムの信頼度および寿 命を長くすることで，高周波でイオンソースのブラズ マをつくることはその1つの方法て，今後実験で評価 する予定である。

正イオン源への研究努力の減少とともに，負イオン を使った中性粒子システムの研究開発が盛んになるて あろら。負イオン源を使った $400 \mathrm{keV}$ の中性粒子シス テムの概念設計图を第 6 图に示す。垁用核融合护飞店 用するに当っては，放射線遮蔽外に大部分のシステム を膡くことが望ましく，たぶんそうせざるを得ないで ある5。最近の3つの分野に打ける進歩がこれを可能 にしたように思われる。すなわち，まず大電流(1A 以上, 定常)のイオンソースが開発された。

次に, strong focusing (transeverse field focusing)加 速和よび輸送概念が丰現できそうであることがかかっ た。また, 消出力, 定常の化学レーザーの急速な進歩に よって photo detachment Kよる, D-イオンの效果的 な中性化が実現できそうになった。Proof-of-principle のため $160 \mathrm{keV}, 1 \mathrm{~A}\left(\mathrm{D}^{-}\right)$, 定常実験を通して，この 3 つの要素がすべて今後研究されるであるう。現在実用 のための目標は，1990年代の初期に tandem mirrorの 実験において，200 keV のビーム打込みを実現させる ことである。

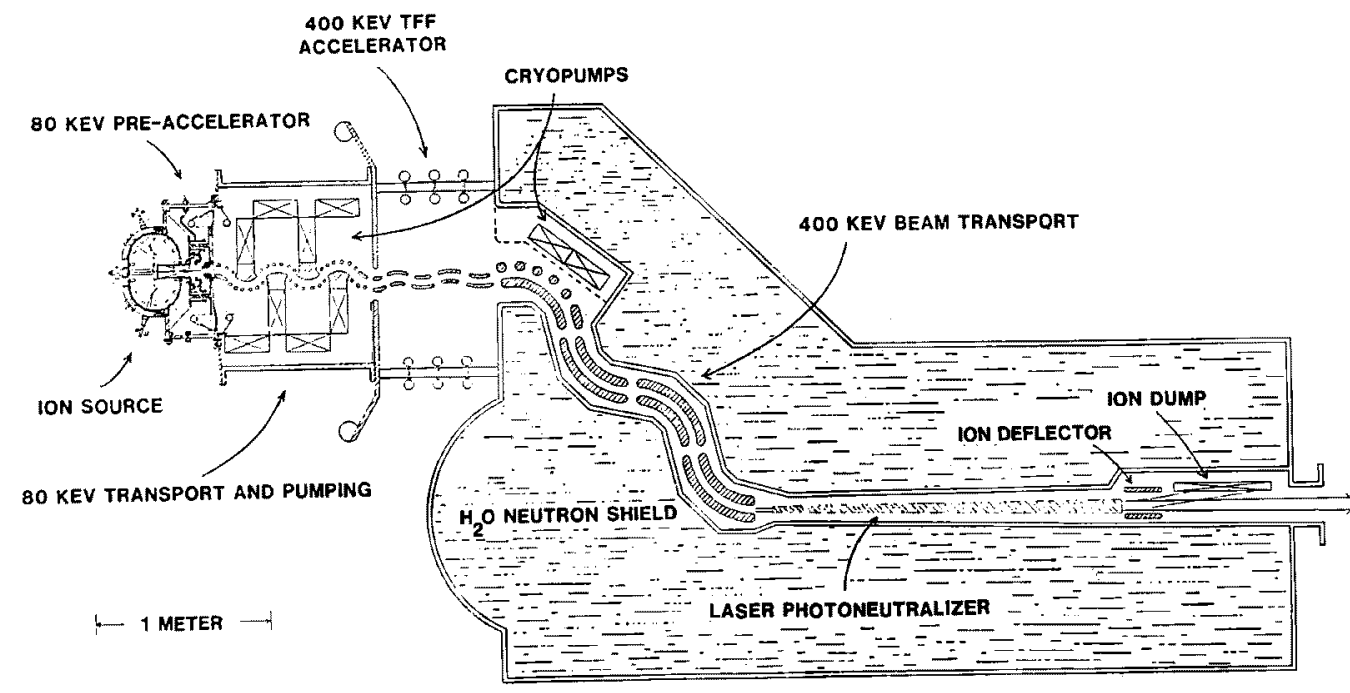

400 KEV NEUTRAL BEAM SYSTEM 2 MW PER METER OF SOURCE LENGTH

第 6 图 $400 \mathrm{keV}$ 中性粒子入射装圈の概念図 
1980年代後半の重イオン核融合加速器研究プログラ 么の目標は，電子密度和よそ $10^{22} \mathrm{~cm}^{-8}$, 電子温度50〜 $100 \mathrm{eV}$ のプラズマをつくり，加速器と beam target 間 の物理的関係を明らかにすることである。パラメータ は块められていないが，現在研究されている例と しては, $10 \mathrm{~ns}$ バルス, $100 \mathrm{MeV}, 3 \mathrm{~kJ} の \mathrm{Na}$ イオンビー ムである。最初の電流パルスは $5 \mathrm{~A} て ゙ 5 \mu$ 予定で かる。

自由電子レーザープログラムの将来は現在の実験結 果次第であり，またある部分はプラズマ加熱のための 短時間大出力マイクロ波のパルスの適合性にも依存し ている。

\section{ท.あとがき}

LBLにおいては，磁気核融合，そして慣性核融合に おける研究扣よび開発，ことに新しい技術のR＆Dが
行われている。これらの新しい技術は，他の国立研究 所や，その他の研究機関でる応用されるだろう。

磁気核融合の分野火扣いては，1990年代初頭までに tandem mirror 実験に利用できる負イオン源を使用し た，中性䊀子入射の技術確立に大部分の努力が注が机 るであろら。

慣性核融合の分野においては，必要な加速器技術の 確立扰上び beam-target の相互作用を解明するため の，高温度実験の設計に努力が注がれるであるら。

紙数の制限のため謝辞ならびに引用を充分取ること ができなかったが，とくに内容や図面等でご配虔頂い たA. Sessler, W. Cooper, D. Keef, K. Ehlersの各氏に 対し感謝いたします。

本研究は米国エネルギー省核融合局との契約 DEAC 03-76 SF 00098 の支援によるものである。

\section{Oセミナー・FA(Factory/Automation)O のための構内通信方式}

主催 日本自動制䃌拁会，窈費 本会ほか13学咕会

会 期 <大隦>9月28日(水) 29 日(木)

会場〈大阪〉大阪科学技街センター 8 階小ホール (大服市西区鞓本甽)

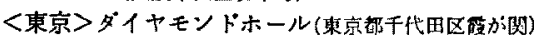
○ブロタラムO

9 月28日・10月 6 日 $(9: 30 \sim 16: 50)$

LAN の開発と標準化動向

FA と PBX

Ring bus

同軸か光か

9 月29日・10月7日

住友電工による実例

一貫慗铁所に和けるネットワークシステム

(日机型氛)岛直 (立石笛嘰)江户鶴男 (神戸大) 岡田博美 (住友触工)加藤正昭 (住友咸工)末 定

(住友金剭)山崎有太郎

トョタ自動車に和ける実例 (トヨ夕自工)末 定

バネル「これからの檏内通信方式」

パネラー (阪大)寺田浩詔, (蛇々公社)千本倖生, (阪大)真田英彦, 他

定 呈 100名(定員になり第䅧切)

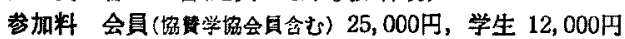

（非会員 35,000 网）(いずれるテキスト 1 冊含む） テキストのみ 会員 3,500円(非会員 4,000円) 申込方法 所定申込書にご記入の上,下記宛へ。 申込先（予606）京都市左京区吉田河原朾14 近鐵地方発明センタービル内

日本自勀制御協会「FAのための構内通信方式」係

(Tel. 075-751-6413)

○「原子カ・バイオハザードに関する○

廃棄物封込技術」特別講演会

主催 日本機械学会，㙝賛 本会ほか 5 学協会

日 時 11月11日(金) 13:00 17:00

会場 ダイヤモンドホール

（來京都干代田区被が関1-4-2、Tel. 03-504-6779) ○ブログム゚

[司会 田中博国 (三機工蔝)，高田秋一(在原紫作所)]

(1) 各程固北封込処理技術(コンクリート・アスファルト プラスチック・ガラス）（萑原製作所)林 忠正

（2）気体液体封込処理技術 (神戸裂鉊)金沢俊夫

(3) 放射性器棄物の保管とモニタリング

(故射楾安全技術センター)町田忠司

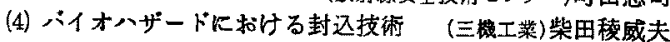

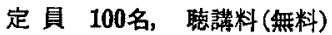

問合せ先（テ151）東京都沾谷区代ね木2-4-9 日.本機珹学会総務課 (Tel. 03-379-6781) 